University of Louisville

ThinkIR: The University of Louisville's Institutional Repository

Faculty Scholarship

Fall 2016

\title{
Aligning circulation policies with student needs and collection value : a historic comparison of trends in academic art libraries.
}

Sarah Carter

Indiana University, saccarte@gmail.com

Follow this and additional works at: https://ir.library.louisville.edu/faculty

Part of the Art and Design Commons, and the Library and Information Science Commons

Original Publication Information

Sarah Carter, "Aligning Circulation Policies with Student Needs and Collection Value: A Historic

Comparison of Trends in Academic Art Libraries," Art Documentation: Journal of the Art Libraries Society of North America 35, no. 2 (Fall 2016): 262-280.

This Article is brought to you for free and open access by ThinkIR: The University of Louisville's Institutional Repository. It has been accepted for inclusion in Faculty Scholarship by an authorized administrator of ThinkIR: The University of Louisville's Institutional Repository. For more information, please contact thinkir@louisville.edu. 


\title{
Aligning Circulation Policies with Student Needs and Collection Value:
}

\section{A Historic Comparison of Trends in Academic Art Libraries}

Sarah Carter, University of Louisville

\begin{abstract}
This article presents contemporary trends in circulation policies as they are applied to art, architecture, and design materials at academic libraries in the United States and Canada. Data from a survey of sixty-nine libraries is discussed in comparison with a similar survey implemented twenty years prior. The author argues that changes in circulation policy should be aligned in part with advances in learner-centered pedagogical practice, while still protecting institutional resources. The article offers suggested assessment methods and areas of potential change for librarians considering reevaluation of their circulation policies.
\end{abstract}

\section{NTRODUCTION}

Joan Benedetti writes in Art Museum Libraries and Librarianship that "access and security are two halves of the same coin." Academic art information professionals know from empirical evidence that this is true, whether they provide service within a special-focus art and design college or at a Research I university. While librarians develop collections to serve users, concerns about materials security over time may lead to policies that limit access. This article reviews current trends in library circulation policies for art, architecture, and design materials at institutions of higher learning in the United States and Canada, with special attention to how learner-centered pedagogy has affected policy over the past twenty years. Since Thomas Gates surveyed

Sarah Carter is assistant professor and director of the Bridwell Art Library, University of Louisville, Louisville, Kentucky; sarah.carter.2@louisville.edu.

I. Joan Benedetti, "A Delicate Balance: Access and Security in the Art Museum Library," in Art Museum Libraries and Librarianship (Lanham, MD: Scarecrow Press; Art Libraries Society of North America, 2007), 44.

Art Documentation: Journal of the Art Libraries Society of North America, vol. 35 (fall 2016)

0730-7187/2016/3502-0007 \$10.00. (C) 2016 by The Art Libraries Society of North America. All rights reserved. 
fine arts libraries in $1995,{ }^{2}$ little research has been done concerning the development of circulation policies for art, architecture, and design materials. With the advent of active learning strategies, higher education has seen the balance of power shift from teacher to student. In some cases, students are encouraged to set the "conditions of learning" within their classroom in order to empower them to take responsibility for their learning. ${ }^{3}$ How do librarians use circulation policies to balance empowerment of student learning with preservation of materials? This article compares the two data sets, the one collected by Gates in 1995 and the other collected by the author in 2015, to discern factors affecting circulation policy change and provide recommendations for art librarians considering their circulation policies.

\section{LITERAT URE REVIEW}

This review approaches three major themes related to the topic. First, consideration is given to historical trends in circulation policy research, including quantitative methods such as availability studies and peer benchmarking as well as qualitative userfocused assessments. Next, relevant literature about the value of art library materials is reviewed. Finally, information-seeking behavior of artists is explored to justify librarians' attention to circulation policies for art and design materials.

\section{DEVELOPMENT OF CIRCULATION POLICY RESEARCH METHODS}

The general literature on circulation policies in libraries is extensive, so only a few key sources are explored for this article's purposes. Outside of the specialized field of art librarianship, many articles have examined the changing nature of circulation policies in academic libraries through the frame of peer benchmarking. Two such examples are found in the writings of Henry DuBois as well as those of Merri Hartse and Daniel Lee, both cited extensively in literature. After a broad survey of forty-three academic libraries in I986, DuBois found that the California State University-Long Beach library decided to lower the threshold for fines at which patrons would be "locked out" or effectively barred from library privileges. ${ }^{4}$ In I992 Hartse and Lee conducted a survey of sixteen peer institutions to determine whether a standardized, end-of-semester due date was regular practice in other libraries. Based upon the survey results, the University of Arizona decided to end its practice of a common, end-ofsemester due date for all materials. ${ }^{5}$

Attention shifted in the I990s from utilizing institutional peer surveys toward userfocused circulation policy assessment methods, such as reviewing institutional use statistics and gathering user feedback through surveys or focus groups. Rather than devel-

\footnotetext{
2. Thomas Gates, "Survey of Circulation Policies in Academic Fine Arts Libraries," LIBRES: Library and Information Science Research Electronic Journal 5, no. 2 (July 3I, I995), http://serials.infomotions.com/libres/libres-v5no2-gates-survey txt.

3. Maryellen Weimer, Learner-Centered Teaching: Five Key Changes to Practice (San Francisco: Jossey-Bass, 2002), $34-37$.

4. Henry J. DuBois, "From Leniency to Lockout: Circulation Policies at Forty-Three Academic Libraries," College Q Research Libraries News, no. II (December I986): 698-702.

5. Merri A. Hartse and Daniel R Lee, "Changing Circulation Policies at an ARL Library: The Impact of Peer Institution Survey Data on the Process." Collection Management I7, no. I/2 (I992): I33.
} 
oping policies that conform to librarian expectations for patron use, librarians began to ask patrons about their needs and study established use patterns. In his frequently cited I999 article exploring circulation and fine policies at the University of Texas Health Science Center, David Shontz concludes from random sampling of over I,500 circulation transactions that circulation fines do have a small effect on timely book returns. The author states, "It is generally accepted that laws must reflect a general consensus of those affected in order to work. An unpopular law will be broken, whether or not there is a penalty." Rupp, Sweetman, and Perry frame their discussion of fine elimination and loan period extensions as a matter of customer service, allowing their front-line staff to "focus on patrons as opposed to punishment." However, evidence for their ten major recommendations for policy change was gleaned largely from staff anecdotes, with additional review of policies from New York University's benchmark institutions, rather than through a user survey. In 20I4, Duane Wilson used a triangulated approach to assess circulation policies at Brigham Young University Libraries, implementing focus groups with patrons, reviewing circulation data to understand current usage patterns, and surveying benchmark institutions regarding their circulation policies..$^{8}$ Each method resulted in three major findings: an undergraduate loan period of three weeks is insufficient, fines are detrimental to user experience, and the existing recall policy is a source of concern for patrons. ${ }^{9}$ At the College of William and Mary, staff noticed an increasing trend of undergraduate renewals. As a result, they lengthened and standardized loan periods for undergraduate students across multiple branches while simultaneously eliminating fines. Their article concludes, "Rather than designing a policy to ensure materials were returned, we designed a policy by first questioning how our user groups wanted to use material." ${ }^{\text {Io }}$

Most recently, Duane Wilson et al. surveyed circulation policies in major academic libraries. ${ }^{\text {II }}$ Among their results, two categories of policies are defined-traditional and non-traditional. The authors argue that traditional policies "are defined as more restrictive in nature and focused on short checkout periods and timely returns," while non-traditional policies "are less restrictive, with more generous circulation and low or no fines." ${ }^{12}$ Examples of traditional loan periods for undergraduates are twenty-

6. David Shontz, "Effect of Fines on Length of Checkout and Overdues in a Medical Library," Bulletin of the Medical Library Association 87, no. I (January 1999): 84.

7. Eric Rupp, Kimberly Sweetman, and David Perry, “Updating Circulation Policy for the 2ist Century,” Iournal of Access Services 7, no. 3 (2010): 159-75.

8. Duane Wilson, “Why Can't They Keep the Book Longer and Do We Really Need to Charge Fines? Assessing Circulation Policies at the Harold B. Lee Library: A Case Study," Iournal of Access Services II, no. 3 (July 20I4): I35-49. It should be noted that the sample criteria were tailored specifically to benchmark BYU. Criteria for inclusion in the sample include ARL libraries (excluding those in Canada and any non-university libraries) and additional non-ARL libraries that were added to the sample based upon data from the National Center for Education Statistics.

9. Duane Wilson, Cynthia Frazier, and Diana Harter, "Circulation Policies in Major Academic Libraries," The Iournal of Academic Librarianship 4I, no. 6 (November 2015): 798-803, doi:I0.IoI6/j.acalib.2015.08.019.

Io. Crystal Boyce, "Practice Makes Perfect: Updating Borrowing Policies and Practices at a Small Academic Library," Iournal of Access Services II, no. 4 (October 20I4): 282-97, doi:Io.Io80/15367967.20I4.945II9.

II. Wilson, Frazier, and Harter, "Circulation Policies in Major Academic Libraries," 798-803.

I2. Ibid., 802 . 
one to thirty days, while non-traditional loan periods are "more than thirty days, with I20 days being the most common." "3 The article calls for a shift in policy toward less restrictive, non-traditional policies to meet current user needs in an era when circulation numbers are decreasing. This approach of traditional and non-traditional circulation policies is explored further in this article in relationship to limitations and possibilities within contemporary art library circulation policies.

From a quantitative perspective, availability studies present a unique lens through which librarians have examined the efficacy of circulation policies and specifically how the circulation of a book to one user may affect all other potential users. Thomas E. Nisonger did a meta-analysis in 2007 of availability studies published between I980 and 200I that utilized Paul Kantor's branching method; this includes thirty-one studies that tested availability at the circulation branch. ${ }^{\mathrm{I}}{ }^{\text {The rate of failure }} \mathrm{T}^{\mathrm{I5}}$ at the circulation branch was surprisingly low, with the weighted mean of failure in locating the book across all studies at 12.6 percent. ${ }^{16}$ This contradicts earlier perceptions that circulation presented a major barrier to success in availability studies. ${ }^{17}$ Discussion of this assessment technique is reviewed later in the article in relation to faculty and graduate student loan periods.

\section{ART BOOK VALUES}

Within the field of art and design librarianship, a few sources are directly relevant to the topic of art book values. Rosann M. Auchstetter confirmed that branch art libraries historically used purchase price as a criterion for restricting circulation of materials, with an average price of $\$$ I5I being the threshold for restricted circulation in I988. However, some librarians did grant circulation privileges to patron groups with higher academic rank, such as faculty and graduate students. ${ }^{\mathrm{I}}{ }^{8}$ Auchstetter's article included a call for more librarians to evaluate their circulation policies, review their collections to determine replacement costs, and allocate funds for replacements. Thomas Gates surveyed art librarians in I995 but was not able to validate his hypothesis that "circulation policies and client loan periods of fine arts libraries may relate to variables such as size, physical configuration, subjects covered, etc." ${ }^{\prime 9}$ However, he found that many librarians placed high value on collections and that fear of materials loss influenced circulation policy. Out of fifty-three responding libraries, fifteen identified themselves as

\footnotetext{
I3. Ibid., 8or.

I4. Paul Kantor's original I976 article outlined four branches or barriers to patron satisfaction in obtaining a desired book: acquisitions (it was not acquired), circulation (it is checked out to another patron), library operations (it is not in the correct shelf location), and the user (it cannot be located when correctly shelved). Later modifications added a bibliographic branch (the user did not have the correct citation) and a catalog branch (the user could not locate the book in the catalog and record the correct call number). Thomas E. Nisonger, "A Review and Analysis of Library Availability Studies,” Library Resources \& Technical Services 5I, no. I (January 2007): 31.

I5. Kantor's method labels failure as the inability to locate a needed material.

I6. Nisonger, "A Review and Analysis of Library Availability Studies," 30-49.

I7. Ibid.

I8. Rosann M. Auchstetter, “The Relationship between Monetary Value and Circulation Status of Art Books,” Art Documentation 7, no. 3 (Fall i988): 83-86.

I9. Gates, "Survey of Circulation Policies in Academic Fine Arts Libraries," 2-4.
} 
non-circulating collections. Gates's survey also identified a wide variety of stakeholders making circulation policy decisions in libraries, including 23 percent that did not involve art librarian input, and 27 percent in which librarians were the sole deciders of circulation policy. Faculty involvement in policy-making was lower than expected. Length of circulation period was found to follow a hierarchical pattern, with faculty granted the longest loan length and undergraduate students receiving a shorter loan period. Gates's survey results are reviewed throughout this article in comparison to new data collected by the author.

A third relevant source is a chapter in Art Museum Libraries and Librarianship, which consists of individual case studies written by three practicing art librarians. ${ }^{20}$ The focus is on the larger issue of access to facilities and materials rather than circulation privileges. The librarians present their institutions' policies as well as methods for implementation for collections and patron groups. The chapter acknowledges the common themes recognizable to academic librarians, such as the tension between access to and security of collections and the need to serve multiple user groups.

\section{ARTISTS' INFORMATION-SEEKING BEHAVIORS}

Any discussion of circulation policies should consider patron information-seeking behaviors. Several researchers have concluded that artists, art students, and art faculty use print books for their research, contrary to previous notions that artists were not disposed toward printed books as research sources. Derek Tonye found in his 1975 article that 22 percent of requests received at the Falmouth School of Art Library were for known-item books. ${ }^{2 \mathrm{I}}$ Russell Ferguson's panel at the joint Art Libraries Society of North America/College Art Association conference in 1986 approached four practicing artists to query their reading habits, which ranged widely through fiction, comic books, and periodicals. ${ }^{22}$ In 1986, Micheline Nilsen wrote of the Montana State University art library's efforts to serve users in a "client-centered" manner by circulating serials for a short loan period. Bound periodical volumes, however, were kept non-circulating due to their utility as a source of imagery, discoverable via indices. ${ }^{23}$ Major findings from Susie Cobbledick's I996 exploratory study include the statement that artists find print resources to be at the heart of the creative process. ${ }^{24}$ Polly Frank concentrates on the information-seeking behaviors of art students, finding that they "need art books to a far greater degree than practicing artists do." 25 In 2004, Sandra Cowan studied artists' information-seeking behaviors outside of a library setting, finding five major

\footnotetext{
20. Benedetti, "A Delicate Balance," 44-53.

2I. Derek Tonye, "Requests at Falmouth School of Art," ARLIS Newsletter, no. 24 (September 1975): 7-9.

22. Russell Ferguson, “CAA/ARLIS Joint Session: 'What Do Artists Read?'” Art Documentation 5, no. 2 (Summer I986): 72.

23. Micheline Nilsen, "Client-Centered Services in a Branch Library," Art Documentation 5, no. 4 (Winter I986): I5I53 .

24. Susie Cobbledick, "The Information-Seeking Behavior of Artists: Exploratory Interviews," The Library Ouarterly 66, no. 4 (October 1996): 343-72.

25. Polly Frank, "Student Artists in the Library: An Investigation of How They Use General Academic Libraries for Their Creative Needs," The Iournal of Academic Librarianship 25, no. 6 (November 1999): 445-55.
} 
sources of information. While printed library materials were not central to her findings, she does mention them among sources consulted by artists. ${ }^{26}$ William Hemmig's 2009 article established that three source types-periodicals, books, and exhibition catalogs-out of six major areas of inspiration used by art practitioners can be found in libraries. ${ }^{27}$ In surveying their preferences for sources of specific visual elements, images in art books were again found to be of above average importance for art practitioners. Most recently in 20II, Helen Mason and Lyn Robinson studied emerging artists in the United Kingdom to determine that they are "enthusiastic users of traditional books, magazines and journals, and of libraries." 28

\section{SURVEY METHODOLOGY}

Data for this article was collected from a voluntary sample by using a forty-question survey distributed online via the ARLIS-L listserv in June $2015 .{ }^{29}$ The author's survey was designed to replicate certain aspects of Thomas Gates's data, as well as explore newer themes related to circulation policies at art, architecture, and design institutions. Sixty-nine unique, valid responses to the online survey were received from librarians in the United States and Canada, each representing a different library. This study involved libraries that were part of a degree-granting institution of higher education, including art and design schools or colleges, but did not include art museum libraries. $^{30}$

The survey asked librarians whether their library circulates materials, and if so, to which user groups they allow circulation privileges. Circulating libraries were asked to specify which groups decide circulation policies and to provide loan lengths for their patron categories. Another question inquired whether materials are shelved in a restricted (or closed-stacks) section and if any are marked for in-library use only. Respondents noted whether their library's loan period to undergraduate students had increased or decreased in length over the past twenty years. The survey asked librarians to rate their perceived satisfaction with their current circulation policy's ability to meet user needs, as well as any changes they would make. Data in free-text

26. Sandra Cowan, "Informing Visual Poetry: Information Needs and Sources of Artists," Art Documentation 23, no. 2 (Fall 2004): I4-20.

27. William Hemmig, “An Empirical Study of the Information-Seeking Behavior of Practicing Visual Artists," Iournal of Documentation 65, no. 4 (2009): 682-703.

28. Helen Mason and Lyn Robinson, “The Information-Related Behaviour of Emerging Artists and Designers,” Iournal of Documentation 67, no. I (2011): I77.

29. The author contacted Gates to inquire whether further details regarding this study were available. Given the passage of two decades, records no longer existed. However, Gates was able to confirm that the directory referred to in the article was in fact the ARLIS/NA Handbook and List of Members, which is available in the ARLIS/NA Archives at the University of Illinois at Urbana-Champaign (Thomas Gates, e-mail message to author, May 6, 20I6). While Gates's article states that "a brief questionnaire was mailed to sixty librarians listed in the ARLIS/NA Directory," identification of institutions was not provided in the article, so direct comparison of respondents is not possible. The fifty-three librarians who responded to Gates's survey represented only a fraction of the over I,900 individuals listed in the I995 ARLIS/NA Handbook and List of Members. The use of the ARLIS-L listserv is an equivalent substitute for the printed handbook used in I995.

30. For a discussion of art museum library use policies, see both Esther Roth-Katz, "Access and Availability: A Study of Use Policies on Art Museum Library Websites," Art Documentation 3I, no. I (Spring 20I2): I23-40 and Joan M. Benedetti, Art Museum Libraries and Librarianship, 44. 
Table 1. Comparison of Libraries Based upon Location of Art, Architecture and Design Books

\begin{tabular}{llc}
\hline & $\begin{array}{l}1995 \\
n=53\end{array}$ & $\begin{array}{l}2015 \\
n=69\end{array}$ \\
\hline Branch libraries & $62 \%$ & $35 \%$ \\
Departmental libraries attached to general libraries & $21 \%$ & $9 \%$ \\
Fine arts collections integrated within the general library & $17 \%$ & $56 \%$ \\
\hline
\end{tabular}

answers throughout the entire survey was coded by the author for frequency of learnercentered and material-centered comments. All respondents answered basic demographic information about whether they worked at a public or private institution and whether their library was a main, branch, or a department or unit within a larger library. Since Gates's findings did not validate the theory that circulation patterns depend on library size, this aspect was excluded from the survey.

In order to make a comparative analysis with the Gates survey, some data recalculation was necessary. Since Gates's data regarding loan length for three users groupsfaculty, graduate students, and undergraduate students - was reported in units of weeks or semesters, the author of this article converted each answer to the corresponding week ranges used in her survey ( $<4$ weeks, $5-8$ weeks, 9-16 weeks, etc.). ${ }^{3 \mathrm{I}}$ This data was used in the comparative charts below. The major weakness of the present study is that the libraries surveyed did not correlate directly to those surveyed twenty years ago. Gates did not publish the list of respondents to his survey, which precluded a more direct follow-up survey.

\section{RESULTS}

Fifty-five percent of respondents were from private institutions and 45 percent worked for public institutions. This sample is similar to Gates's survey, which included 47 percent private institutions and 53 percent public institutions. ${ }^{32}$ Table I reveals a significant shift over the last twenty years regarding the location of art books, which now reside more often in the general library rather than at branch libraries. ${ }^{33}$ Fifty-six percent of art materials were kept at the main library in 2015 as compared to only I7 percent in I995. The number of departments managing art, architecture, and design materials within general libraries was down notably by I2 percent. In Table 2, the data shows that only six libraries reported completely non-circulating

3I. Gates's survey included responses of "carrel" and "varies," which were not included as possible answers to the 2015 survey. In the case of "carrel," those answers were converted to non-circulating, while "varies" was excluded from the data set.

32. Gates, "Survey of Circulation Policies in Academic Fine Arts Libraries," 3.

33. This aligns with the results published in Stephen A. Patton and Kristina M. Keogh, "The Branch Art Library in ARL Institutions: A Longitudinal Study and Environmental Scan,” Art Documentation 34, no. 2 (Fall 20I5): $249-66$. 
Table 2. Comparison of Libraries that Allow Circulation of Art, Architecture, and Design Materials

\begin{tabular}{lcc}
\hline & 1995 \\
& $n=53$ & $\begin{array}{l}2015 \\
n=69\end{array}$ \\
\hline No & $28 \%$ & $9 \%$ \\
Yes & $72 \%$ & $91 \%$ \\
\hline
\end{tabular}

art collections in 20I5, while in I995 fifteen libraries answered that their collections did not circulate to any extent. When compared to Gates's report twenty years earlier, the rate of non-circulation has dropped is percent.

Gates found that faculty held fewer than expected decision-making roles in setting circulation policies regarding fine arts materials. ${ }^{34}$ In subsequent years, faculty, subject librarians, and committees have all lost influence over policy-making, whereas administrators have assumed a stronger role in this area (Figure I). Some survey comments point to standardization of loan periods in their institution for consortial lending, which would be an administrative decision. Certainly, the centralization of art collections within larger institutional libraries would also mean that administrators may have taken the initiative to create consistent lending policies. Two respondents to this survey explained that their non-circulating policies are "historic" or an "original library mandate."

\section{LONGITUDINAL COMPARISON OF CIRCULATION PRIVILEGES ACROSS USER GROUPS}

Comparison of data from both surveys in Table 3 shows that the three primary user groups - faculty, graduate students, and undergraduate students-have the same or increased circulation privileges after twenty years. Ninety-eight percent of institutions surveyed loan art, architecture, and design materials to faculty, which was the same percentage found in Gates's survey. Concurrently, the percentage of institutions reporting circulation privileges to graduate students has risen by 22 percent and undergraduates by 24 percent. Three other secondary user groups-curators, alumni, and public/unaffiliated users-included in this survey are granted circulation privileges by a majority of institutions. Sixty-eight percent of institutions surveyed allow alumni to borrow items, while only 55 percent allow curators the same privileges. Public/unaffiliated users are less likely to enjoy circulation privileges in 20I5, since institutions allowing for circulation to the public are down I4 percent in the last twenty years. A new category of user, "other groups," 35 was included in the 2015 survey.

34. Gates, "Survey of Circulation Policies in Academic Fine Arts Libraries," 6.

35. The most frequent description of this "other" group was consortial borrowers, but it also included visiting lecturers, K-I2 educators, institutional trustees, members of a neighborhood association, high school students, and donor/ members to the institution and/or library. 


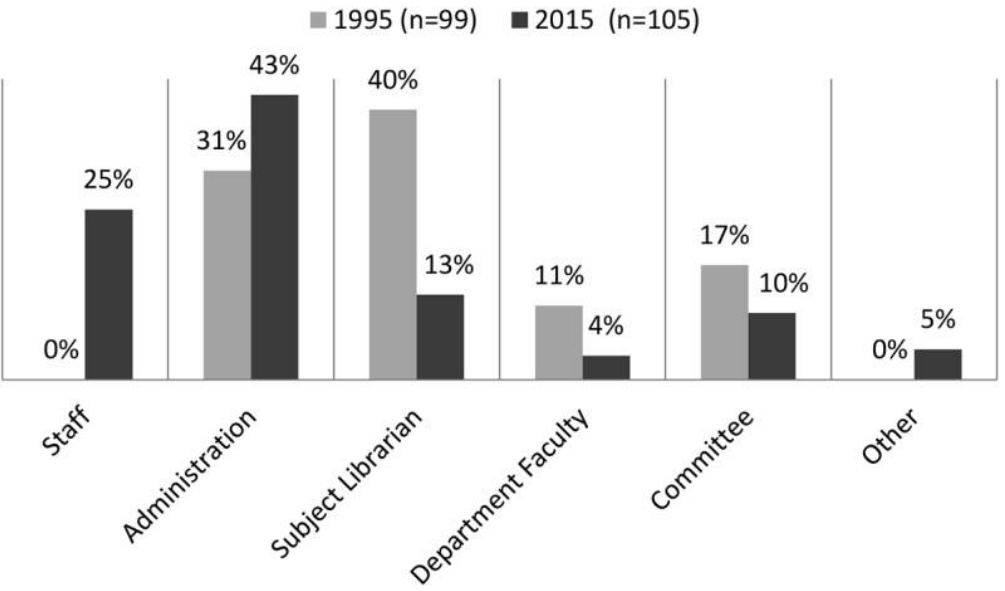

Figure 1. Comparison of circulation policy decision makers in 1995 and 2015. Each respondent was able to select more than one answer.

Table 3. Comparison of Libraries that Allow Circulation by User Groups

\begin{tabular}{|c|c|c|c|c|c|c|}
\hline & \multicolumn{3}{|c|}{$\begin{array}{c}1995 \\
n=53\end{array}$} & \multicolumn{3}{|c|}{$\begin{array}{l}2015 \\
n=69\end{array}$} \\
\hline & Yes & No & NA & Yes & No & NA \\
\hline Faculty & $98 \% 36$ & $2 \%^{37}$ & - & $98 \%$ & $2 \%$ & - \\
\hline Graduate & $67 \%$ & $20 \%^{38}$ & $13 \%$ & $89 \%$ & $5 \%$ & $6 \%$ \\
\hline Undergraduate & $70 \%$ & $20 \%$ & - & $94 \%$ & $3 \%$ & $3 \%$ \\
\hline Alumni & - & - & - & $68 \%$ & $30 \%$ & $2 \%$ \\
\hline Curator & - & - & - & $55 \%$ & $16 \%$ & $29 \%$ \\
\hline Public ${ }^{39}$ & $65 \%^{40}$ & $35 \%$ & - & $51 \%$ & $46 \%$ & $3 \%$ \\
\hline Other groups & - & - & - & $60 \%$ & $40 \%$ & - \\
\hline
\end{tabular}

36. This includes one library that reported that its policy "varies."

37. This does not include the seven respondents who reported circulating materials to be used only in the building.

38. Of the eleven libraries in this category, five allowed students to place materials on carrels, but (presumably) those carrels were located within the library.

39. In Gates's survey, this category was termed "Other/Non-affiliated."

40. Again, one library reported that its policy varied when loaning materials to the public/unaffiliated users. 


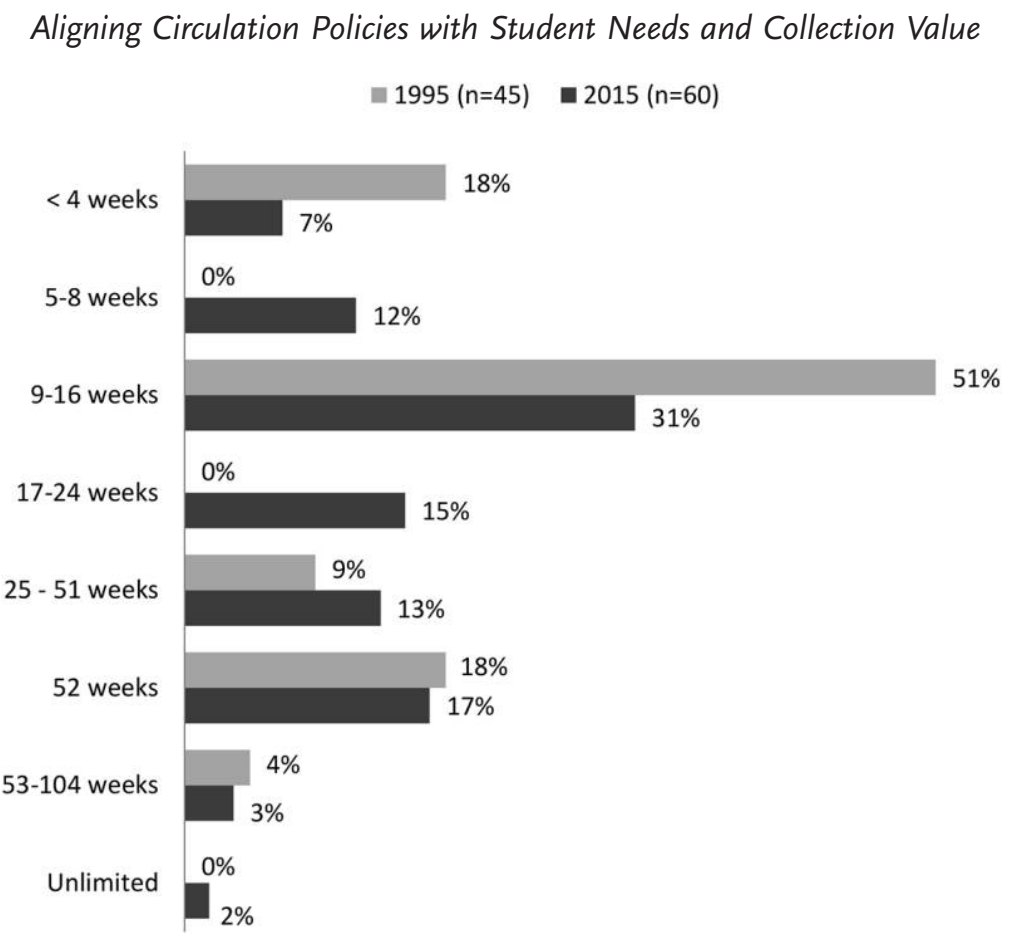

Figure 2. Longitudinal comparison of loan length to faculty.

These patrons are given circulation privileges at 60 percent of the institutions surveyed, many of which specified that patrons must verify state residency to receive a borrower's card.

\section{LONGITUDINAL COMPARISON OF LOAN LENGTHS ACROSS PRIMARY USER GROUPS}

In comparing loan lengths of primary user categories from both surveys, results show an overall increase in privileges, most noticeably away from the shortest loan periods. The percentage of institutions loaning materials to faculty for less than four weeks is down from 18 percent to 7 percent, and loans of five-to-eight weeks (a previously nonexistent category) total I2 percent (Figure 2). A similar shift can be observed in the nine-to-sixteen-week and seventeen-to-twenty-four-week categories. Graduate students saw the most dramatic change in loan length, with a shift of 53 percent of institutions offering circulation for less than four weeks in I995 to only I8 percent in 2015 (Figure 3).

Undergraduate students' privileges have shifted the least in the last twenty years. Gates's research indicates that the average loan length in I995 to undergraduates was four weeks. ${ }^{4 \mathrm{I}}$ Further comparison with his data in Figure 4 shows that in I995, 47 percent of libraries surveyed allowed their books to circulate one-to-three weeks, which now stands at 29 percent, while the four-to-six-week category has risen from

4I. Gates, "Survey of Circulation Policies in Academic Fine Arts Libraries,” I3. 


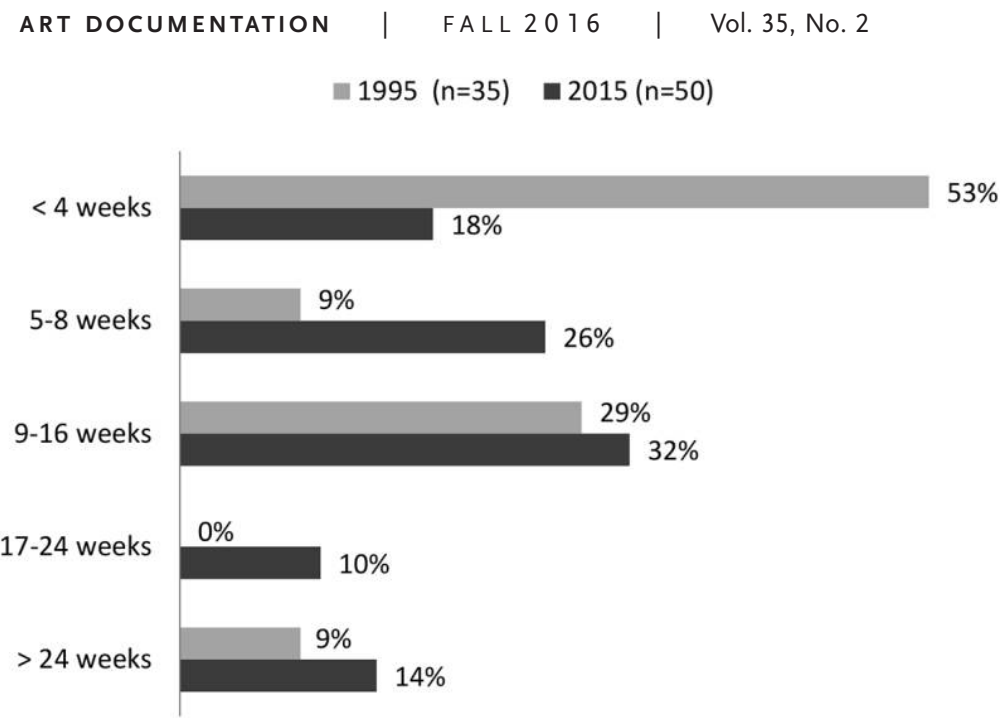

Figure 3. Longitudinal comparison of loan length to graduate students.

45 percent in 1995 to 54 percent. Current circulation loan lengths have increased even more, with 8 percent of libraries now allowing seven-to-twelve-week loans, and an additional 9 percent allowing loans of more than twelve weeks. In contrast, Gates's survey revealed no libraries allowing loans of seven-to-twelve weeks.

\section{LOAN LENGTHS TO SECONDARY USER GROUPS}

Of the three secondary user groups surveyed in this study, only the public/unaffiliated group matched Gates's data. Loan privileges to members of the public (Figure 5) have decreased only slightly in the past twenty years, indicating that they are still considered

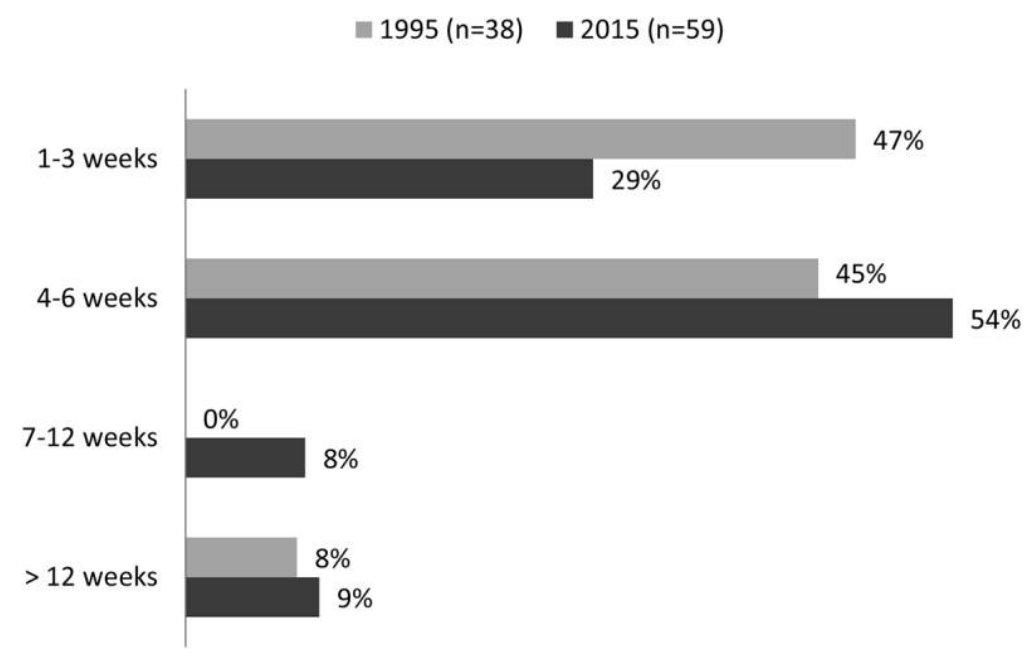

Figure 4. Longitudinal comparison of loan length to undergraduate students. 


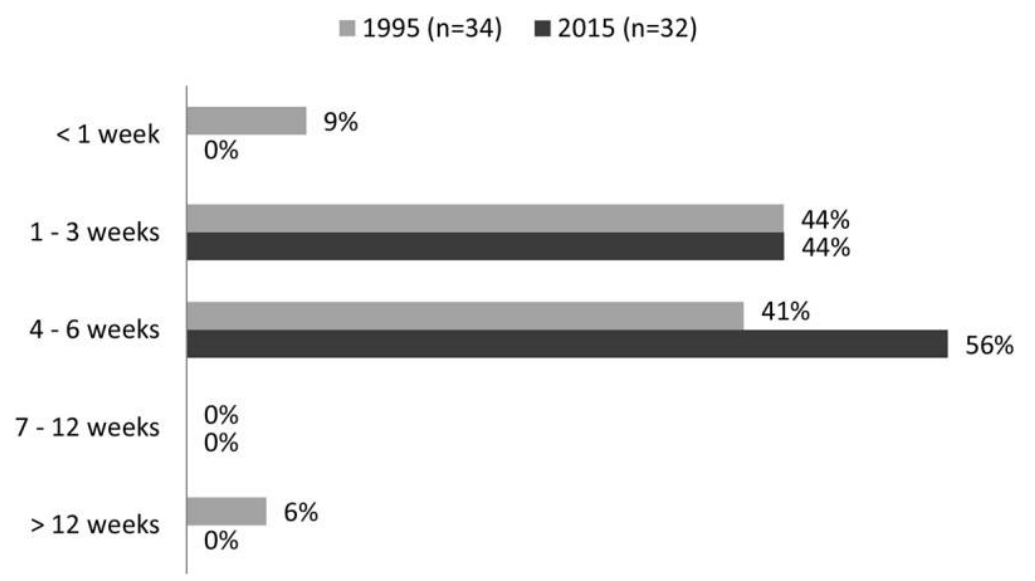

Figure 5. Longitudinal comparison of loan lengths to public groups.

a secondary audience for the majority of libraries who loan their materials. ${ }^{42}$ While Gates concluded in 1995 that undergraduates and public users enjoyed similar loan lengths, ${ }^{43}$ this is no longer the case since undergraduate borrowers have generally surpassed the public in loan length over the last twenty years.

Two new user categories were examined that did not appear in Gates's survey to test the theory that curators and alumni may be granted privileges greater than public borrowers (Figure 6). The majority of institutions that loan to curators have established a sixteen-week checkout period. Many survey respondents indicated that curators have faculty status at their institutions. Alumni are granted loan periods of either one-to-three weeks (40 percent) or four-to-eight weeks ( 58 percent), and only one library grants more than an eight-week checkout. Curators are given relatively long loan privileges compared to undergraduate students; the length exceeds graduate student loan periods only slightly.

\section{ACCESS TO COLLECTIONS AND REPLACEMENT VALUES}

The author coded all free-text comment fields in the survey for phrases or words indicating material-centered or learner-centered policy factors. Material-centered concerns were mentioned eighteen times throughout the survey, while learner-centered comments arose ten times. Browsing was mentioned frequently, especially in relationship to limitations of off-site storage or closed-stack storage. This shows that librarians are aware of the implications of their decisions to place materials in a location that limits patron access. Sixty-eight percent of respondents indicated that some

42. See Terrie Wilson's article for an overview of the challenges and benefits art libraries face serving secondary users: "The Community User in the Academic Art Library," Art Documentation 24, no 2 (Fall 2005): 38-42.

43. Ibid., 39. 
- Alumni $(n=43) \quad$ Curator $(n=35)$

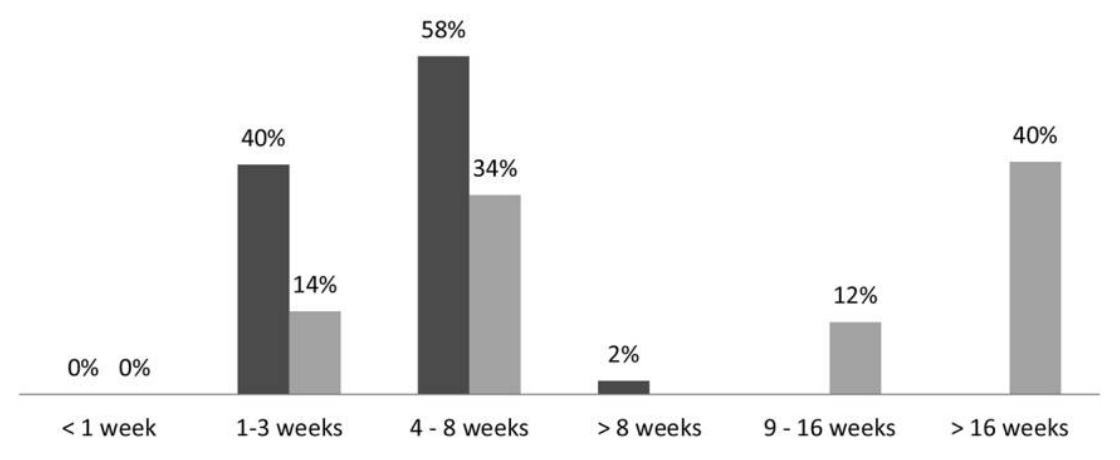

Figure 6. Loan lengths to alumni and curators.

portion of their collection is kept in a location inaccessible to patrons for browsing. Of these respondents, 64 percent reported that less than io percent of the collection was kept in restricted areas. A few art librarians commented that they would prefer to keep more of their materials in closed stacks, but that lack of space prevented them from doing so.

Vandalism was mentioned once in this survey by one librarian who stated that her context was more conservative, and thus "books about Nan Goldin's work, for example, are often vandalized (mostly for censorship purposes). Ideally, I would love to have everything in open stacks, but after I replace the same book more than five times, I start to become convinced that some should be in closed stacks. The problem with that is we don't have the space to create closed stacks, and Special Collections is desperate for space, too."

Open stacks can lead to a lack of accountability for each patron-book interaction. In such cases, shelving location may be the only solution that could protect materials from being vandalized. However, if a book on Goldin were charged to a patron's account and returned damaged, the library might still have some recourse for cost recovery. The survey also reveals that 62 percent of all libraries surveyed designate a portion of their materials (other than reserves or reference) as "library use only"; most oversize materials or volumes with loose plates were mentioned in this category.

Of the material-centered comments, the concept of book value (including replacement value) was primary. Unsurprisingly, even after twenty years, the replacement value of art, architecture, and design materials remains a barrier to wider circulation for some libraries. Librarians report evaluating item value before sending books for interlibrary loan, as well as checking item values periodically to determine whether they should be moved to a restricted shelving location. One librarian mentioned that items valued over $\$ 500$ are designated as non-circulating but are available in open stacks for browsing. No respondents addressed methods for cost recovery in the survey. 


\section{PAST AND POTENTIAL FUTURE CHANGES TO LOAN POLICIES}

When asked about changes to their circulation policies over the past twenty years, librarians' answers were almost evenly split among three categories (Figure 7). Almost a third of the sixty-nine institutions did not know whether their undergraduate policies had changed in the last twenty years. This likely reflects that respondents did not have the institutional memory to report policy changes. The 30 percent that reported an increase in loan length touched upon a variety of ways their libraries made policies more favorable for undergraduate students, such as more renewals, elimination of fines, and an increase from three- to four-week loan periods for undergraduates. Several respondents commented in this and in other sections of the survey that standardization of loan length was desirable for consortial agreements. Finally, just over 7 percent of institutions reported that policies have remained the same as they were twenty years ago. Although this survey did not ask respondents for their reasoning in maintaining policies, one may assume that they believe existing policies balance the needs of users and collections. However, 36 percent of those who indicated their policies remained the same since 1995 also indicated that they would like to make changes to the policy, such as allowing students to borrow books for up to twenty-four hours or moving high-value books from storage to open shelving but restricting their use to the library. This signals learner-centered focus and flexibility on the part of librarians to meet changing user needs.

Factors leading to increased circulation policies in the past twenty years were split between academic program growth (i9 percent), changes to undergraduate research and study habits ( 24 percent), and undergraduate student demand (30 percent). Twentyseven percent of respondents cited miscellaneous reasons for change, including adherence to consortial loan periods, which was mentioned the most frequently.

The survey asked librarians to rate their satisfaction with the current policies to meet overall user needs on a scale of I (Dissatisfied) to 5 (Satisfied). Mean satisfaction

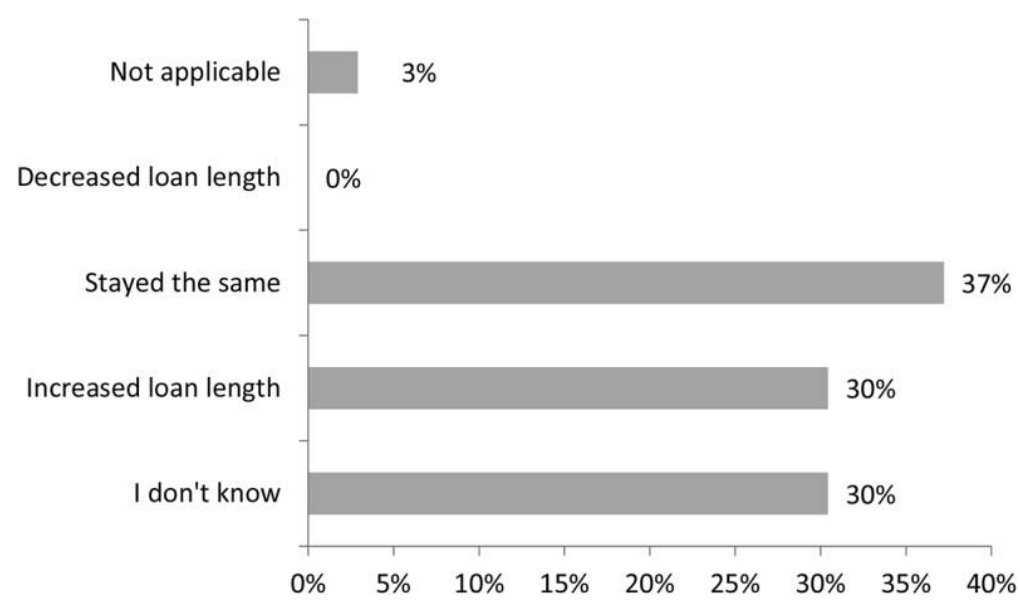

Figure 7. Changes to undergraduate circulation policy since 1995. 
Table 4. Sample of Suggested Future Circulation Policy Changes

\begin{tabular}{|c|l|}
\hline Proposed Changes to Loan Periods & Proposed Changes to Number and Type of Items \\
\hline $\begin{array}{c}\text { Standardizing loan periods for oversize } \\
\text { and regular stacks books }\end{array}$ & $\begin{array}{c}\text { Increasing total number of items which may be } \\
\text { borrowed by a user at one time }\end{array}$ \\
\hline $\begin{array}{c}\text { Shortening faculty and graduate loan } \\
\text { length periods }\end{array}$ & $\begin{array}{c}\text { Decreasing the number of non-circulating items } \\
\text { in the otherwise-circulating collection }\end{array}$ \\
\hline $\begin{array}{c}\text { Increasing loan periods for undergraduate } \\
\text { and graduate students }\end{array}$ & Lending videos to secondary user groups \\
\hline $\begin{array}{c}\text { Creating consistent loan periods between } \\
\text { other branch libraries on campus }\end{array}$ & Circulating oversize books \\
\hline Allowing circulation to students & Circulating bound periodicals \\
\hline Allowing more renewals & \\
\hline $\begin{array}{l}\text { Refusing more loans to consortial and } \\
\text { public users }\end{array}$ & \\
\hline
\end{tabular}

from respondents was 4.2. Respondents were also asked whether they would change their circulation policies. Sixty-eight percent responded that they were satisfied with their current policy, while the remaining 32 percent indicated that they would make changes. In a follow-up question, respondents offered many areas of desired change for their users and materials. Four strong themes emerged: elimination of fines, accessibility of collections for browsing, adjusting the number and/or type of materials that may be borrowed, and changes to loan periods (Table 4).

\section{DISCUSSION AND RECOMMENDATIONS}

\section{CHANGES IN LOAN LENGTH}

The general trend of loan length standardization for art materials with those in other disciplines may be considered a result of more art, architecture, and design materials now being housed in main library collections than there were twenty years ago. The practice of standardizing loan lengths provides patrons clearer, more consistent policies for their use of materials across disciplines. Librarians and faculty are more likely to have less decision-making power in light of consortial agreements and growing administrative influence over policy.

While the survey's findings revealed a consistent increase in loan periods for the three primary user categories, adherence to hierarchical privileges remains the norm. Gates's research on faculty input into loan policies showed that they did not exert much influence over the decision-making process in 1995, and this survey has found only a slight decrease in influence in the past twenty years. However, survey data 
shows that while loan length has increased for all three primary user groups (Figures 2, 3, and 4), faculty enjoy disproportionately longer loan periods, with significant increases in the seventeen-to-twenty-one-week loan category, a slight increase in the twenty-five-to-fifty-one-week category, and the new unlimited loan category. Gates's theory states, "Perhaps the nature of a more general curricula at the undergraduate level precludes the notion of in-depth research and study; if this is the bias then it would follow that undergraduates need a shorter loan period and graduate students a longer one especially since the latter must produce scholarly papers." ${ }^{44}$ An alternative explanation for this phenomenon is faculty circulation privilege inflation; that is, as undergraduate and graduate loan lengths have increased, policy-makers have felt internal or external pressure to increase faculty privileges further. Whatever the reason, the overall trend seems to be increasing the privileges of the most-privileged group rather than establishing equality for all groups.

Interestingly, the idea of shortening faculty and graduate student loan periods was proposed by at least one librarian in this survey as a desirable change. In Paul Kantor's aforementioned study, he determined that a change in circulation loan period-from a semester loan period to a four-week loan period-accounted for a 7 percent reduction in failure to locate materials at the circulation branch. ${ }^{45}$ In some situations, the reduction of loan periods or renewal privileges for one or more user groups may benefit the wider scholarly community by ensuring that books are available on the shelf more frequently.

\section{TENSIONS BETWEEN PRESERVATION AND ACCESS}

Data from this survey indicates a continuing tension between concern for materials - their loss, damage, vandalism, and ensuing replacement costs-and support of users in their scholarly and creative work. Librarians may choose to adopt some non-traditional, learner-centered circulation policies as a way to meet changing pedagogical expectations. At a time when higher education is focused increasingly on assessment of student learning, libraries may want to reexamine their policies in light of how they contribute toward student success. One survey respondent mentioned that the policy changes within the past twenty years had been the result of a "careful and deliberate study" at her institution. While the survey did not query librarians specifically about whether an assessment of policies had been conducted, another librarian described an in-depth process at her institution that involved discussions with administrators, student representatives, and a national review of student usage patterns before making policy changes.

Since Auchstetter wrote in I988 about the high replacement cost of art, architecture, and design materials, costs have risen further, and one assumes they will continue to increase in the future. Access to out-of-print titles may be easier thanks to e-commerce. But, in the case of very limited print runs, even if one is able to locate the

44. Gates, "Survey of Circulation Policies in Academic Fine Arts Libraries," II.

45. Paul B. Kantor, "Availability Analysis," Iournal of the American Society for Information Science 27, no. 5 (September I976): 3II-I9. 
title for sale online, the cost may be prohibitive due to shrinking budgets. Methods used to address material-centered concerns-in-library-use-only designations, closed stacks, checking book replacement prices before loaning through interlibrary loanremain much the same as twenty years ago. As mentioned previously, alumni and community patrons receive the shortest loans of all groups surveyed. These are the two groups from whom it may be the most difficult to recover materials. ${ }^{46}$ An enrolled student or employed faculty member is tied to the institution in a way that allows libraries to penalize them should they fail to return materials. As resources become more valuable, circulation to secondary user groups without formal employment at or enrollment in institutions has become more marginalized.

Space also continues to be a concern. Several librarians mentioned their need for closed stacks, but they are unable to find a way to integrate this into their facilities. If librarians cannot provide secure locations for materials prone to vandalism, they may be left with few alternatives - to abstain from collecting such items or to spend precious collection development dollars replacing books. Off-site storage is a newer element that was not present in Gates's study. It affects patrons' browsing capabilities but allows for protection of materials from vandalism. Interlibrary loan and consortial lending, which were not mentioned in Gates's research, now reflect contemporary approaches to collection management in light of budget and space concerns for many libraries.

\section{LEARNER-CENTERED POLICIES}

Gates's findings revealed that librarians observed specific use patterns that they believed were prohibitive to circulation, such as a "very high demand ... in terms of patron-per-book use, resulting in a need to limit or prohibit circulation." 47 Contemporary librarians in this survey, however, did not mention such behavior dictating policy. With the availability of electronic journal articles, research habits have shifted in part to the use of online sources. In fact, one librarian commented in this survey that circulation privileges were extended since usage of physical resources had been declining. Librarians who mentioned circulation changes in favor of accessibility and student success made comments such as the following:

Speaking as a former fine art student myself, I think it's very important for students to be able to use books in their own studio and creative spaces, for inspiration when/where it's most needed, and to have physical access to browse and discover these materials on their own. Full value is realized when these beautiful and relatively expensive resources are well used even though some deterioration and loss may be inevitable. I have found that our students tend to be good stewards on the whole, and in any case, I am much more excited to

46. For a discussion of alumni access policies, including how long-tail theory and influence theory can be used as tools to cultivate alumni relationships and donations by extending circulation privileges, see Natalie Burclaff and Johannes Britz, “Alumni Access Policies in Public University Libraries," Inkanyiso 3, no. I (20II): I-I2.

47. Gates, "Survey of Circulation Policies in Academic Fine Arts Libraries," 4. 
find the catalogs and surveys in our collection with a few dog eared pages or random flecks of paint than those that are pristine but covered with dust!

This view of wear and tear on library materials becomes evidence that collections are serving learners well. The librarian's comments represent a paradigm shift from comments in Gates's survey, in which one librarian responded that "books are too valuable, too soon out of print to risk more loss." ${ }^{8}$ The situation at this particular library may not accurately reflect the reality of most librarians but is one example of how libraries can use learner-centered policies to support student learning within an institutional context. Especially given the wide-ranging sources of inspiration documented by researchers (Cobbledick I996, Frank I999, Hemmig 2009, Mason and Robinson 20II) as well as the unsuitability of some artistic practices outside of specialized studios (those with ventilation or certain types of lighting, for example), learner-centered policies may be considered especially important for art library patrons.

When asked about motivations for changes in circulation policies, another art librarian said, "The dean of libraries felt strongly that the loan rule should be the same for faculty, graduate students, and undergrads. In practice this can be (but is not often) problematic, but if the university bills itself as "student-centered," the policy reflects the university's tagline. If the student (presumably undergraduate) is at the center of the enterprise, why should we not lend material in a similar fashion?"

This comment regarding a more liberal policy is a reflection of learner-centered teaching methods, as expressed in pedagogical literature by Maryellen Weimer in 2002. ${ }^{49}$ As teachers have worked to empower students to take responsibility for their own learning, perhaps more non-traditional circulation policies may further empower them. Suggestions that Weimer made almost fifteen years ago to involve students in participatory decision-making now can be seen in current library practices of holding student focus groups about policies as well as studies of circulation data that reveal actual study habits. Although a slight majority of institutions surveyed have maintained the same circulation policies since I995, a subset within these respondents see justification for making future changes.

A continuum of approaches to circulation policies exists in art libraries, and this study has found a shift in overall policy toward the learner-centered approach in the past twenty years. However, 7 percent of librarians report that their institutions have not changed their policies in the last twenty years. While learner-centered approaches have gained traction within circulation policies, some librarians continue to uphold the status quo. Unfortunately, this survey did not query librarians' reasons for maintaining their policies, so any suggested motives would be purely speculative.

\section{FUTURE OPPORTUNITIES FOR CHANGE}

Although the mean satisfaction of librarians with their circulation policies' ability to meet patron needs is high, 32 percent of all respondents stated that they would like

48. Ibid.

49. Weimer, Learner-Centered Teaching, 34-37. 
to make changes to their current policies. Table 4 shows that while the majority of librarians are satisfied with their current policies, they are also flexible in thinking about how their users could be better served while still maintaining security of materials. Librarians should assess their users, preferably using multiple modes of assessment. ${ }^{\circ}$ Art librarians may conduct quantitative and qualitative assessments of their libraries' circulation policies from customer satisfaction and circulation analysis perspectives. Librarians may decide to use customer satisfaction surveys, conduct a review of customer complaint logs, or implement focus groups to determine the satisfaction level with circulation policies_-and whether there are confusing aspects for patrons. Issues relating to customer satisfaction with circulation policies may also be revealed in LibQUAL+ service superiority gap scores as well as in statistical data from past circulation transactions for number of renewals and average length of days between checkout and return. Art librarians should assess the theft, damage, and loss rates at individual libraries and determine the overall impact on the collection and its users. Kantor's branching method can be used to collect data about book availability in the collection, which may indicate whether user groups with longer circulation privileges cause high rates of failure in finding materials.

For art librarians, tension between learner-centered and material-centered priorities will likely remain for another twenty years and longer. Each librarian is charged with making collection decisions to serve specific institutional priorities, and adopting non-traditional circulation policies may not be possible for every art library. However, librarians should continually revisit circulation policies to protect their collection investment while serving patron needs in the face of changing pedagogical contexts.

50. For an example of triangulated assessment methods, see David K. Larsen, "Assessing and Benchmarking Access Services," in Twenty-First Century Access Services: On the Frontline of Academic Librarianship, ed. Michael J. Krasulski Jr. and Trevor A. Dawes (Chicago: Association of College and Research Libraries, 2013). 